\title{
Modelling wheat yield responses to soil and climate variability at the regional scale
}

\author{
T. Wassenaar ${ }^{1, *}$, P. Lagacherie ${ }^{1}$, J .-P. Legros ${ }^{1}$, M. D. A. RounsevelI ${ }^{2}$ \\ ${ }^{1}$ UFR Science du sol, IN RA M ontpellier, F-34060 cedex 2, France \\ ${ }^{2}$ Department of G eography, Université Catholique de Louvain, place Louis Pasteur, B-1348 Louvain-La-N euve, Belgium
}

\begin{abstract}
We present a study on the impact of soil and climatic variability on the yield of winter wheat in the Hérault-Libron-Orb Valley in southern France. The study was based on the use of a crop simulation model (Euro-ACCESS), run at 63 individual sites throughout the study area, for the current climate (1976 to 1984) and for potential future changes in temperature and precipitation (2047 to 2054). Three climate scenarios were selected to represent low, mid and high changes, although significant winter wheat yield decreases were only observed for the climate scenario with the largest change. In general, the influence of climate change on yields was small (less than $0.1 \mathrm{t} \mathrm{ha}^{-1}$ over the whole simulation period), but strong inter-annual variation was found, which is typical of the Mediterranean climate. Soil variability within the study region was the most important source of spatial variability for the simulated yields, and the soil available water capacity was identified as a good indicator of yield change for large climatic change. Soil variability was important in this study because of the small size of the study region and because of the strong influence of water limitation on crop growth in M editerranean areas. Statistical relationships were established between crop yields, yield changes and the soil available water capacity. These relationships were used to extrapolate the crop simulation results from individual sites to the whole region using data from soil maps at a scale of 1:250000. This modelling exercise demonstrated the importance of explicit consideration of soil as well as climatic variability in crop-climate impact studies.
\end{abstract}

KEY WORDS: Crop modelling $\cdot$ Climate change $\cdot$ Spatial variability $\cdot$ Winter wheat $\cdot$ Climate variability $\cdot$ Soil variability

\section{INTRODUCTION}

The assessment of climate change impacts on human societies and the implementation of response strategies should be underpinned by detailed scientific understanding of the magnitude and rate of climate change impacts on agriculture. Such impacts have recently been analysed using process-based crop models to predict crop yields under both current and future climate conditions (Kenny \& Harrison 1992, Bindi et al. 1996, Wolf et al. 1996, Conde et al. 1997). The crop models used in these studies were designed to run for single points on the earth's surface. However, the scientific understanding that is required to make policy responses to climate change is most often required at

\footnotetext{
*E-mail: wassenaar@ensam.inra.fr
}

the regional, national or continental scales. This has led to the coupling of model simulations and spatialisation techniques that deal with the soil and climate variability of a region of interest. The general approach to achieve this is based on stratifying the region into a set of geographical units in which average crop yields are estimated. Where the spatialisation procedure aims to estimate average yields within large administrative units, e.g. a U.S. county, it was demonstrated that optimal accuracy could be obtained by running simulations from the means of soil and climate input parameters estimated for coarse pixels, i.e. respectively $2.8^{\circ} \times$ $2.8^{\circ}$ and $1^{\circ} \times 1^{\circ}$ (Easterling et al. 1998). At this scale, soil variability seems to provide little explanation of the observed variation in modelled yields with respect to climate. This is probably because most of the soil variation occurs within the target units whereas broadscale climate variability influences inter-unit variation. 
However, the impact of climate change on agriculture at regional scales will be underpinned by the response of individual farms, and understanding climate impacts at the farm level requires investigation at the large scale (Easterling et al. 1998). At large scales, the importance of soil variability increases relative to climate variability. The main reason for this is that soil variability can be very high in the range 0.1 to $10 \mathrm{~km}$. For example, in France, Favrot (1989) calculated from a set of detailed soil surveys performed over the whole French territory that an average of 28 soil classes were recognised within each small natural region (on average $300 \mathrm{~km}^{2}$ ). This soil variability is likely to have an effect on potential crop yields under present and future climate conditions, and the magnitude of the effect needs to be investigated. Spatialisation techniques also need to be designed to map climate change impacts in relation to soil and climate variability at these large scales.

In this paper, we examine from a set of representative sites how wheat yields simulated with a processbased crop model are influenced by soil and climate variability observed within a small natural region $\left(1200 \mathrm{~km}^{2}\right)$ located in the south of France. To map crop yields over the study region, soil and climate influences are summarised through a set of response curves that estimate crop yields for each type of climate from the soil available water capacity (AWC). We present an example of the mapping of climate change impacts using these response curves.

\section{MATERIAL AND METHODS}

We present here a description of the crop model used in the analysis, the climate and soil variability in the study area and sites selected for simulation, and the estimation of future climate change.

2.1. Modelling wheat yields. The crop model used in this study (EuroACCESS) was designed by a team of European researchers within the framework of a European Commission funded project (Loveland et al. 1994, Loveland \& Rounsevell 1996, Armstrong et al. 1996). The model comprises 2 parts: a crop model and a soil water balance model. The crop model part (Legros et al. 1994) simulates both the leaf growth to calculate the actual evapotranspiration from the potential evapotranspiration and the root growth to define the size of the reservoir that supplies water to the crop. It is derived partly from the EPIC model developed by the USDA (Williams et al. 1989) and partly from ARCWHEAT (Weir et al. 1984) and CORNGRO (Childs et al. 1977). EPIC was modified to allow the possibility of working, inside the crop period, with adapted parameters for each crop phenophase, i.e. EPIC-PHASE
(Debaeke et al. 1996). As with EPIC, EuroACCESS is able to deal with several annual crops if the parameters describing them are available. Evapotranspiration is partitioned into transpiration of the plant and evaporation from the soil that remains bare. The partition is made following Beer-Lambert's law taking the LAI (leaf area index) as an exponential parameter (Ritchie 1972, Feddes et al. 1978). Transpiration is given by the root extraction in relation to a theoretical root density calculated by the method of Childs et al. (1977).

In the water balance part of EuroACCESS (Leenhardt 1991, Legros et al. 1996) the soil profile is divided into $5 \mathrm{~cm}$ layers, the physical and chemical properties of the layers being the same if they fall within the same pedological horizon. However the water content of each layer varies independently to better represent the transfers in the soil and the effects of root extraction. Water movement from a layer to the one situated immediately below is simulated taking into account the excess of water above the field capacity and a factor linked with the saturated hydraulic conductivity (Floret et al. 1982). Evaporation at the soil surface is calculated from the humidity of the first layer, but capillary rise is not simulated directly; the evaporated water is assumed to be furnished by several layers near the surface, the contribution of each being estimated on the basis of an exponential decrease with depth (Van Keulen 1975). If water is lacking, the transpiration is reduced, and the growth is limited according to the coefficient 'actual transpiration/potential transpiration'. The data and parameters required for running EuroACCESS are given in Table 1.

The model runs on a daily basis and has been tested on data sets from experimental sites in England, France, Poland and Spain (Legros \& Bonnet 1996). The fundamental concepts of the model make it more powerful in southern European regions, where the lack of water strongly influences crop growth (Debaeke et al. 1996), than in northern regions, where low temperatures are the main limiting factor (Henric et al. 1996).

The calibration of EurOACCESS in the study region was difficult because the average yields in the Languedoc departments (Table 2) are less than half of the yields obtained at corresponding experimental stations for most of the tested varieties (ITCF, 1990). The reasons for this are numerous. In particular, wheat is not considered to be an important crop in the region, but just as a means of keeping the soil clean between 2 cycles of vines. Under these conditions, the calibration of the model was based on 2 principles: when the water stress does not intervene, the aim is to simulate a yield as obtained in the experimental sites for the best tested varieties; to obtain a relative yield fluctuation 
Table 1. Main data and parameters of the EuroACCESS model

\begin{tabular}{|c|c|c|}
\hline Input data & Internal parameters & Output data \\
\hline Soil profile & Soil & Crop output file \\
\hline Attainable rooting depth & \multirow{3}{*}{$\begin{array}{l}\text { Van Keulen (1975) coefficients to } \\
\text { calculate the evaporation in relation } \\
\text { with the soil top water content }\end{array}$} & Length of the cropping period \\
\hline & & Water lost by bottom drainage \\
\hline Soil horizons & & Total biomass obtained \\
\hline Thickness & \multirow{2}{*}{$\begin{array}{l}\text { Relation curves between soil water } \\
\text { and corresponding water potential }\end{array}$} & Yield (grain in tonnes ha-1) \\
\hline Bulk density & & \\
\hline Hydraulic conductivity & \multirow{3}{*}{$\begin{array}{l}\text { Rambal \& Cornet coefficients (1982) to } \\
\text { calculate actual transpiration from } \\
\text { soil water potential }\end{array}$} & Daily output file \\
\hline Water content for saturation $\left(\mathrm{g} \mathrm{g}^{-1}\right)$ & & Date \\
\hline Water at field capacity $\left(\mathrm{g} \mathrm{g}^{-1}\right)$ & & Crop phenophase reached \\
\hline Water at wilting point & Crop & Degree-days accumulated \\
\hline Air dry water content & Optimum temperature for growth & Leaf Area Index (LAI) \\
\hline Initial water content & Minimum temperature for growth & Root depth reached \\
\hline & Degree-days for maturity & Water and thermal stresses \\
\hline Climate (for each day) & Maximum leaf area index & Biomass and above ground biomass \\
\hline Lowest temperature & Date of leaf area decrease & Actual evaporation and transpiration \\
\hline Highest temperature & Maximum root depth & Water content for the whole profile \\
\hline Rainfall & Root density (Childs et al. 1977) & (Position of the water table) \\
\hline Global radiation & $\begin{array}{l}\text { Coefficients to calculate the efficiency } \\
\text { of conversion from solar energy to } \\
\text { dry-matter production }\end{array}$ & $\begin{array}{l}\text { Regional file (per soil type) } \\
\text { Crop type }\end{array}$ \\
\hline Crop & & Soil water retention cap. of the soil \\
\hline Name & & Remaining water at the harvest day \\
\hline Sowing date & & Yield (grain in tonnes ha-1) \\
\hline
\end{tabular}

Table 2. Real mean yields in tonnes ha ${ }^{-1}$ in 4 departments of the M editerranean coast in and near the study area during the period considered (Statistiques Agricoles, 1977-1984)

\begin{tabular}{|lcccccccc|}
\hline & 1977 & 1978 & 1979 & 1980 & 1981 & 1982 & 1983 & 1984 \\
\hline Aude & 2.9 & 2.8 & 3.1 & 3.3 & 3.4 & 2.8 & 3.7 & 4.7 \\
Gard & 2.2 & 2.7 & 3.0 & 4.1 & 3.0 & 2.2 & 3.0 & 3.7 \\
Hérault & 2.2 & 2.7 & 2.2 & 3.6 & 2.9 & 2.5 & 3.1 & 3.4 \\
P. Orientales & 2.8 & 1.9 & 2.4 & 2.6 & 2.0 & 1.5 & 1.8 & 1.9 \\
\hline
\end{tabular}

between years that is similar in size to the simulations and the field results (a variation of about $\pm 25 \%$ for the 1977 to 1984 period). Thus, instead of representing actual yields the simulations give the yield that would be obtained on the different soils under the current climate for optimal farming conditions.

2.2. Soils and climate in the study area and selection of simulation sites. The study was undertaken in the Hérault-Libron-Orb valleys region (Fig. 1), located $60 \mathrm{~km}$ west of Montpellier and covering an area of approximately $1200 \mathrm{~km}^{2}$. The region exhibits typical northern Mediterranean climatic characteristics, i.e. (1) substantial average annual rainfall (on average $\left.700 \mathrm{~mm} \mathrm{yr}^{-1}\right)$, (2) high within-year rainfall variability with rainfall peaks in autumn and spring, and summer droughts, (3) high between-year rainfall variability, (4) frequent and violent rainstorms, and (5) large potential evapotranspiration (PET) (on average $\left.1000 \mathrm{~mm} \mathrm{yr}^{-1}\right)$, as a consequence of the high average temperature and radiation, as well as frequent and strong winds. As shown by the weather stations located in the vicinity of the studied region (Fig. 2), the temperatures exhibit only small variations across the studied region. Conversely, the 11 rainfall stations located within the region (Fig. 3) reveal a strong within-region variability (annual rainfall between 570 and $810 \mathrm{~mm}$ ) which follows a clear south-north gradient. PET measurements are only available from $2 \mathrm{cli}$ matic stations, Narbonne and Montpellier-Fréjorgues (Fig. 3), which are situated at either side of the region, $100 \mathrm{~km}$ from each other. The difference in annual average PET registered at each of these stations does not exceed $6 \%$.

The soil pattern in this region is extremely complex, mainly because of large geological variations. The substratum is a heterogeneous $\mathrm{M}$ iocene marine sediment 


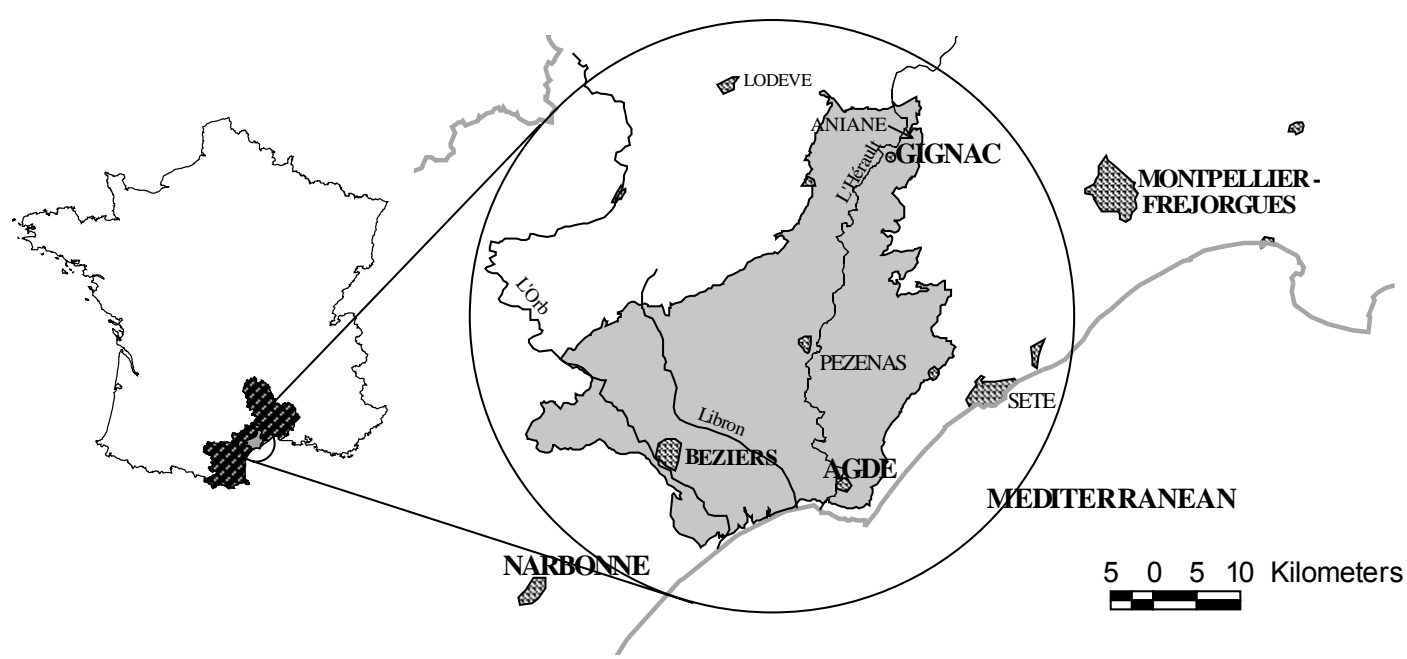

Fig. 1. Location of the study area in the Languedoc Roussillon region, France

from which have formed either lithic leptosols, calcaric regosols or calcaric cambisols (FAO-UNESCO, 1981). This substratum is partially overlain by old and middle-aged alluvial deposits that become thicker from north to south. These deposits have produced stony soils ranging from calcaric to chromic luvisols. The most recent alluvial deposits contain calcaric fluvisols and are located in the alluvial plains of the rivers. Local volcanic activity and recent colluvial phenomena add to the soil heterogeneity. This variability is described by the soil information system of the Languedoc Roussillon (Bornand et al. 1994) through 36 landscape units which include a total of 96 soil typological units.

A selection of the simulation sites was made to take into account the soil and climate variability of the region. Twenty-six soil profiles located within the study region with appropriate data inputs for the
EuroACCESS model were extracted from the Languedoc-Roussillon soil database (Bornand et al. 1994). These profiles represent the range of soil types occurring in the region in terms of their hydraulic properties as indicated by soil surveys (Bonfils 1993, Bornand et al. 1992, Leenhardt et al. 1994). Simulation runs on profiles of soil types that would obviously not be employed for wheat cultivation (such as very stony leptosols) were excluded from results presented here. This step was taken to avoid a bias of soil type with respect to climate. To enhance the statistical significance and extrapolation of the wheat yield response curves simulations were undertaken for 63 soil profiles. The 37 additional profiles included those previously excluded as well as profiles located in the vicinity of the study region which can be allocated to one of the soil types of the region.

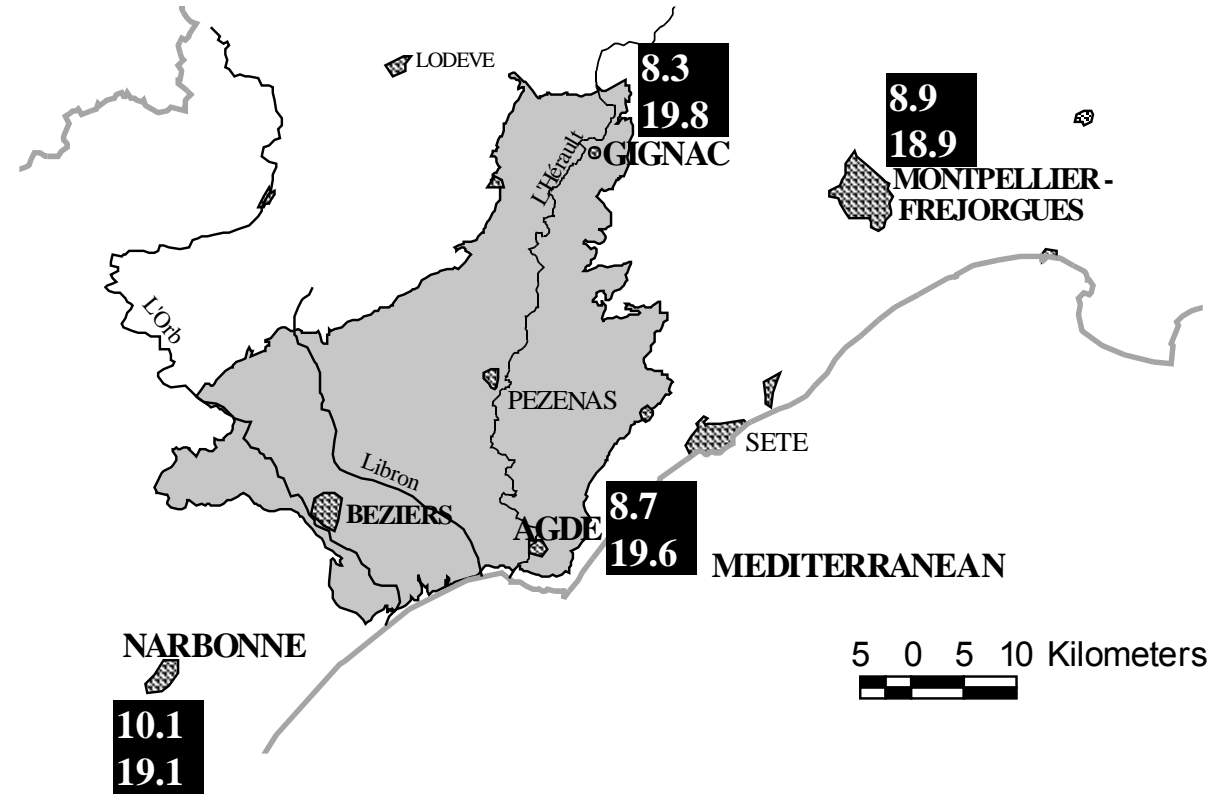

Fig. 2. Average annual means of minimum and maximum day temperatures $\left({ }^{\circ} \mathrm{C}\right)$ of the climate stations in and around the study area (Kessler \& Chambraud 1986) 
Fig. 3. Average annual rainfall amounts (mm) as measured by the rainfall stations in and around the study area (Kessler \& Chambraud 1986)

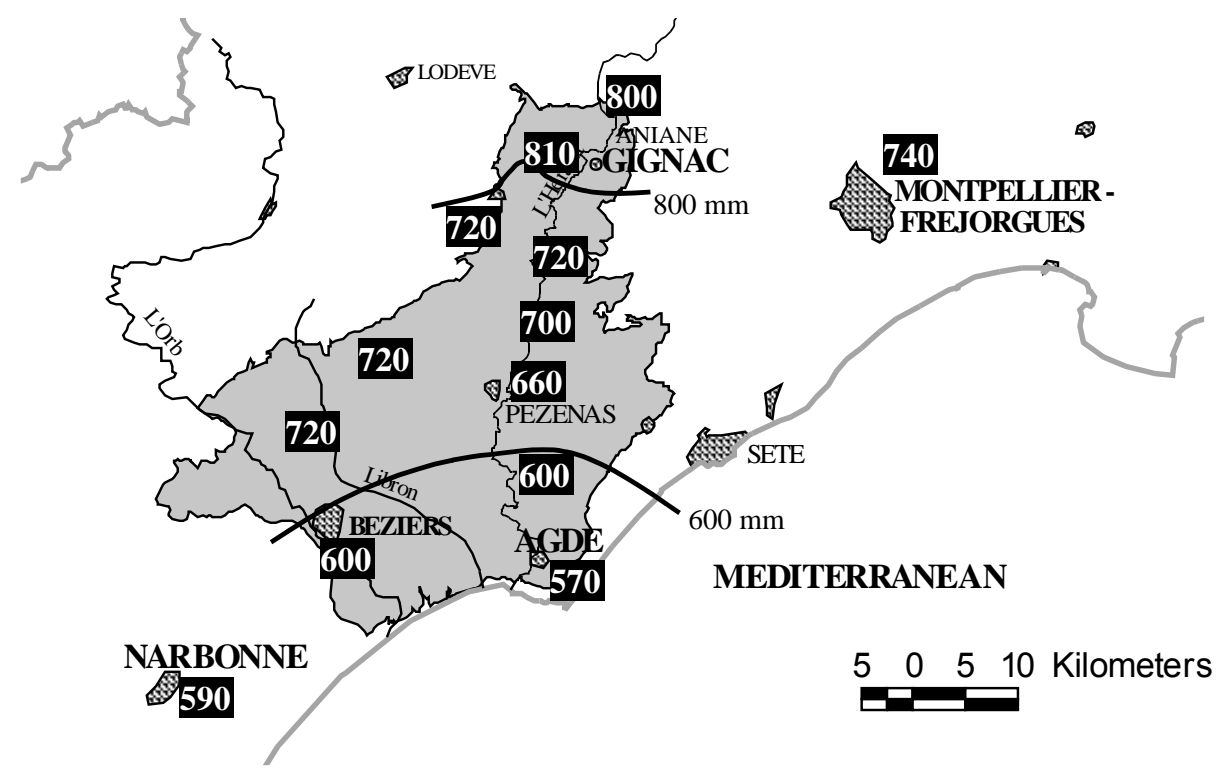

The climate variability of the region was considered using a set of theoretical climate stations which were defined by assembling daily input data from available stations located within and near the study region. As shown in Figs. $2 \& 3$, temperature and PET exhibit only very slight variations throughout the region, which allows a unique data set of daily parameters to be selected. The only climate stations providing complete time series of daily temperature, radiation and PET were Montpellier-Fréjorgues and Narbonne. Montpellier-Fréjorgues was finally selected since its annual temperatures appear more representative of the study area (Fig. 2). Three rainfall stations, Béziers, Pézenas and Aniane, were selected to represent the southnorth gradient associated with change in elevation as this is the only noticeable climatic trend affecting the region (see Fig. 3).

The 26 soil profiles were combined with the 3 selected climate stations to obtain 78 theoretical soilclimate situations, which represent the range of soilclimate spatial variation observed within the region. A total of $189(3 \times 63)$ soil-climate situations were also considered when establishing the response curves. In order to represent the large inter-annual variation of the Mediterranean climate, 8 successive years were considered between 1976 and 1984. This period includes both extremely dry and wet years.

2.3. Future climate change estimation. 2.3.1. The EUROSCEN climate database: Future temperature and precipitation scenarios were derived from the EUROSCEN database system (Rounsevell et al. 1998). EUROSCEN is a simple software tool which enables the user to exploit results from both simple and global climate model experiments (all reported by IPCC, 1995), using different greenhouse gas emissions sce- narios and 'climate sensitivities' (Hulme et al. 1995). This is combined with European baseline climates $\left(0.5^{\circ}\right.$ spatial resolution) to construct a range of geographically explicit future climate change scenarios for Europe.

On the basis of the data and climate change scenarios predicted by EUROSCEN, different hypothetical 'climates' were estimated for the 3 locations (Béziers, Pézenas and Aniane) around the year 2050 (EUROSCEN cell $40^{\circ} \mathrm{N}, 0^{\circ} \mathrm{E}-45^{\circ} \mathrm{N}, 5^{\circ} \mathrm{E}$ ). The HADCM 2 model was selected for use in this study, because it has been used in a wide range of climate impact assessments and thus provides an appropriate benchmark for comparison among impact studies. In order to assess the significance of the climate change impact derived from HADCM 2, 2 further model scenarios were needed to indicate the range of variability in future climate predictions. The models used to represent extreme scenarios were the Goddard Institute for Space Survey's model (GISS) for low change and the Hadley Centre UKHI model for high change. The characteristics of the 3 selected change scenarios (LOW, MID and HIGH) are summarised in Table 3. It should be noted that this selection was based on annual change factors. M onthly predictions among the 3 scenarios are very variable. These intra-annual differences will probably have a large influence on crop development, especially in combination with the large differences between summer and winter weather currently observed in the region.

2.3.2. Imposition of climate changes: The EUROSCEN parameters used to calculate the future climate by perturbation of the 1976-1984 baseline data were: change in mean monthly temperature $\left({ }^{\circ} \mathrm{C}\right)$; cumulative monthly rainfall change (\%); change in the 
Table 3. General characteristics of the selected EUROSCEN scenarios. Climate sensitivity is expressed as the magnitude of the equilibrium surface global warming following a doubling of $\mathrm{CO}_{2}$ concentration in the atmosphere

\begin{tabular}{|c|c|c|c|c|c|c|c|}
\hline $\begin{array}{l}\text { Change } \\
\text { scenario }\end{array}$ & $\begin{array}{l}\text { Climate } \\
\text { sensitivity }\end{array}$ & $\begin{array}{l}\mathrm{CO}_{2} \text { emission } \\
\text { scenario }\end{array}$ & $\begin{array}{l}\text { Global change } \\
\text { model }\end{array}$ & Temp. $\left({ }^{\circ} \mathrm{C}\right)$ & $\begin{array}{r}\text { Annua } \\
\text { Rain (\%) }\end{array}$ & $\begin{array}{l}\text { al change } \\
\text { Wet days mo-1 }\end{array}$ & Cloud cover (\%) \\
\hline MID & $\operatorname{Mid}\left(2.5^{\circ} \mathrm{C}\right)$ & IS92a (mid) & HADCM 21995 & +1.8 & -0.9 & -1.0 & -1.8 \\
\hline LOW & Low $\left(1.5^{\circ} \mathrm{C}\right)$ & IS92C (low) & GISS 1983 & +0.7 & -0.2 & - & -1.0 \\
\hline $\mathrm{HIGH}$ & $\operatorname{High}\left(4.5^{\circ} \mathrm{C}\right)$ & IS92e (high) & UKHI 1989 & +3.5 & -5.8 & - & -6.5 \\
\hline
\end{tabular}

Table 4. Winter wheat simulation periods ( ) ulian days) for the different climate change scenarios

\begin{tabular}{|ccccc|}
\hline Maturity (day-degrees) & Actual period & Period for MID scenario & Period for LOW scenario & Period for HIGH scenario \\
\hline 2300 & $316-176$ & $316-156$ & $316-171$ & $316-146$ \\
& $(227 \mathrm{~d})$ & $(207 \mathrm{~d})$ & $(22 \mathrm{~d})$ & $(197 \mathrm{~d})$ \\
\hline
\end{tabular}

number of wet days per month (day fraction, for HADCM 2 only); monthly cloud cover change (\%). The influence of elevated atmospheric $\mathrm{CO}_{2}$ concentrations on crop growth and water use was not considered in this analysis. On the basis of these parameters the climate data required by EuroACCESS were calculated (i.e. minimum and maximum day temperatures, daily rainfall, global radiation, daily $\mathrm{PET}$ ).

This approach resulted in 3 sets of parameters, obtained on the basis of the 3 different EUROSCEN scenarios, which were applied to the selected climate data of Béziers, Aniane and Pézenas, resulting in 9 future climates.

2.4. Running EuroACCESS at simulation sites. The soil water balance was calculated continuously from J ulian day 300 of 1976 to J ulian day 365 of 1984 (8 fallow and winter wheat cycles). This led to more realistic yield results than the independent simulation of individual years because soil-water conditions resulting from one year's simulation affect the initial conditions of subsequent years. As a result of this continuity, the simulation periods for wheat need to be determined as accurately as possible. The length of the growth period to maturity is directly related to accumulated day-degrees, so some runs were made using data for the coldest year (1977) to determine the required duration for the wheat simulation. Average starting dates were established from several unpublished technical reports and available literature on winter wheat cultivation in the region (Begon 1992, Kenny \& Harrison 1992, Bonnet 1995), and a good average seemed to be to 'sow' in the second week of November (J ulian day 316 was chosen). The day-degrees needed for a wheat crop to reach maturity were specified in the crop-input files. For winter wheat a well-calibrated input file for the region was available (Debaeke et al. 1996), with an accumulated temperature to maturity of 2300 day-degrees. Changes in the growth period to maturity, caused by climatic change (i.e. decrease), were simulated by changing the harvest date (Table 4) in line with test runs. The shortening of the crop growth period caused by temperature rise varied from $5 \mathrm{~d}$ (LOW scenario) to $30 \mathrm{~d}$ (HIGH scenario).

\section{RESULTS AND DISCUSSION}

\subsection{Wheat yields for the current climate}

Fig. 4 shows that wheat yields simulated for the current climate without irrigation ranged from 4 to $7 \mathrm{t}$ $\mathrm{ha}^{-1}$, averaged over all soils, with a mean around $5 \mathrm{t}$ $\mathrm{ha}^{-1}$. A comparison with real wheat yield data for the region over the simulation period (Table 2 ) shows the

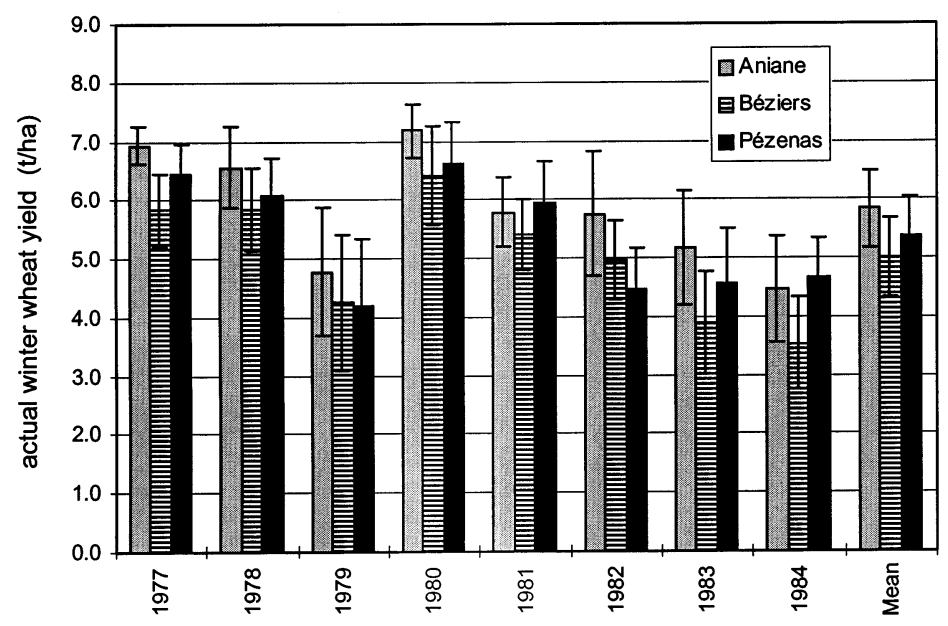

Fig. 4. Averaged annual wheat yields under current climate conditions. Error bars indicate standard deviation of yield over the entire range of soils 
same differences as observed between real wheat yield data and yields from experimental farms. The average yields registered in the 4 departments of the Languedoc region were found to be $40 \%$ of the estimated yield using EuroACCESS. This 'yield gap' between actual and modelled data results from less than optimal management practices and appears to be within the range observed elsewhere (Van Lanen et al. 1992). The difference between observed and estimated annual yields tends to reduce slowly over the period of study as the quality of farming increases. A part from this trend, the simulations performed with EuroACCESS seem to represent the inter-annual variations of yields observed well during the period.

The yields reported from experimental stations (Braun et al. 1990) correspond very well to the simulation results. In 1990 at experimental farms around Nîmes (less than $100 \mathrm{~km}$ east of the study area at about the same distance from the coast) yields of 12 tested varieties varied from 5.0 to 7.6 $\mathrm{t} \mathrm{ha}^{-1}$. A little irrigation was applied, which may explain the slightly higher yields. However, a precise comparison is not possible since the different data sets originate from different years with different weather conditions.

Fig. 4 provides insight into the sensitivity of the crop model to soil and climatic spatial variability. The variability of estimated yield due to the variation of rainfall within the region (BéziersPézenas-Aniane) is generally limited (less than 1 $\mathrm{t} \mathrm{ha} \mathrm{a}^{-1}$ ) and as expected (i.e. the lowest yield is recorded in the driest climate). Conversely, soil property variability gives rise to substantial yield variability, the mean standard deviation $( \pm 2 / 3$ total variability) being around $\pm 1 \mathrm{tha}^{-1}$.

\subsection{Wheat yield responses to temperature and precipitation changes}

Fig. 5 presents the absolute yield differences between the current climate simulations (1976 to 1984) and the yields resulting from simulations using respectively the LOW, MID and HIGH climate change scenarios. Fig. 5 shows that the LOW and MID scenario results do not differ markedly, the LOW scenario resulting in a slight increase in mean yield whereas a very slight decrease in yield may be expected for the MID change scenario. Only under the most extreme climate change scenario (HIGH) can a clear and general decrease in yield be expected. The relationship between successive years remains the same, but the
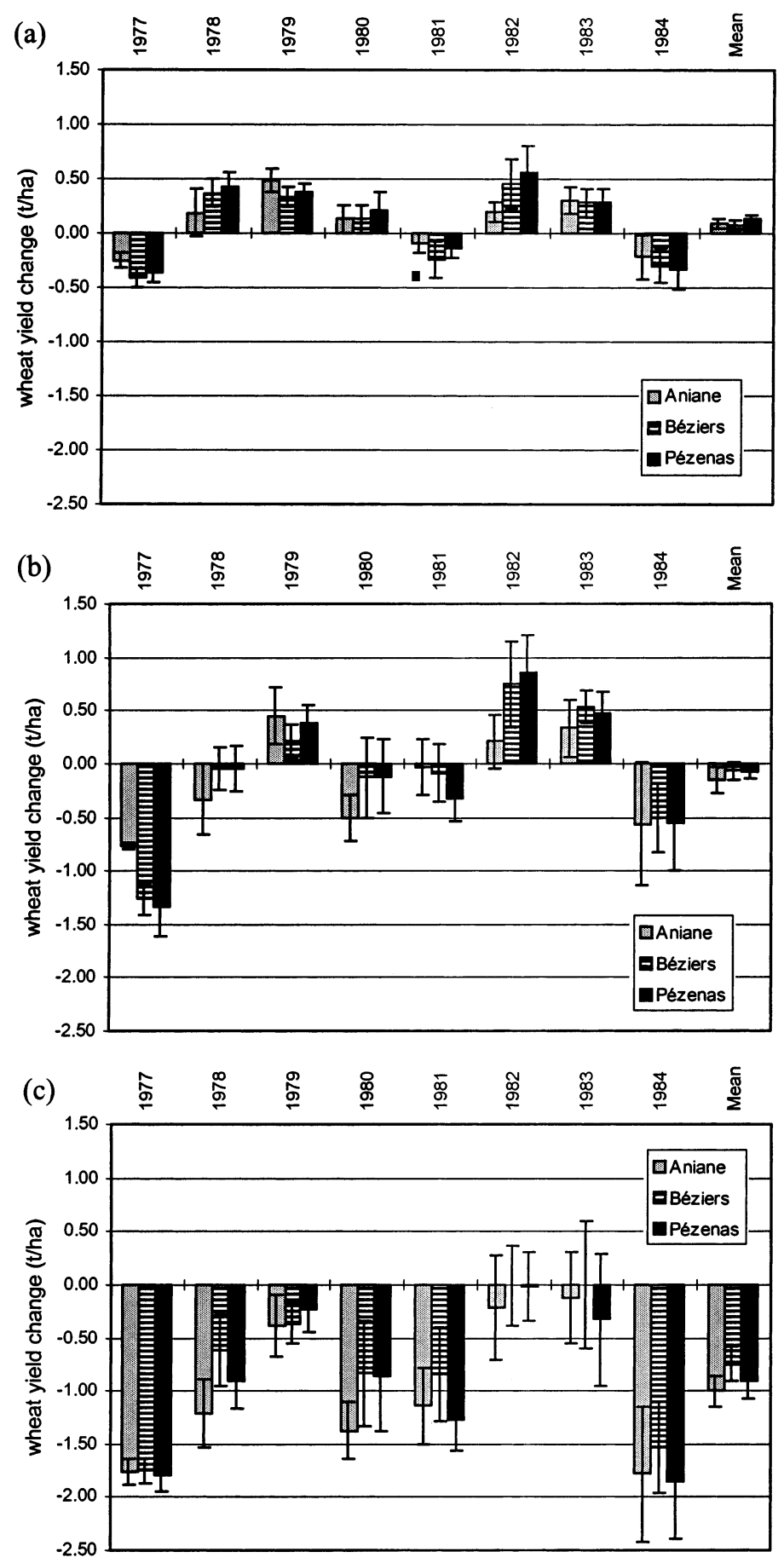

Fig. 5. Winter wheat yield difference between the 1976-1984 period and the hypothetical 2046-2054 period, calculated on the basis of (a) GISS, (b) HADCM 2 and (c) UKHI climate change scenarios. Standard deviations between individual soil profiles are indicated with error bars

yield change generally shifts by at least $-0.5 \mathrm{t} \mathrm{ha}^{-1}$. This results in an average yield decrease of around 0.8 $\mathrm{t} \mathrm{ha}^{-1}$, varying over the $8 \mathrm{yr}$ period from 0 (1982 $\rightarrow$ '2052') to $1.7 \mathrm{t} \mathrm{ha}^{-1}(1984 \rightarrow$ '2054'). 
The influence of soil (error bars, Fig. 5) and climate (bars, Fig. 5) spatial variability on simulated crop yields increases from the LOW to HIGH scenario. However the effects of soil are more significant than climate for all scenarios, the difference becoming increasingly large from the LOW to HIGH scenarios. Under the LOW change scenario, which predicts only slight monthly rainfall changes, the influence of soil hydraulic properties on wheat yield variability is small. Temperature and radiation changes represent more important stress factors and, therefore, the variability among soil types of change in soil available water plays a minor role. The significance of soil available water increases in the M ID and HIGH scenarios and so the influence of soil variability becomes dominant.

\subsection{Deriving wheat yield response indicators from simulation results}

Simulations of crop growth can only be undertaken for a limited set of typical situations at which input parameters of crop models are measured. To extend the results to an entire region remains difficult because precise estimations of these parameters are rarely available in regional geographical databases. We propose, therefore, an alternative approach that aims to establish statistical relationships between the simulation outputs and indicators that occur in geographical databases. In the case study presented here, these relationships take the form of climate-specific regressions between a soil indicator and average yields (or average yield change when climate change is considered). The selected soil indicator was available water capacity (AWC) defined by the Soil Science Society of America as the amount of water (percentage by weight) released between in situ field capacity (soil matric potential of $-0.030 \mathrm{MPa}$ ) and the permanent wilting point (usually estimated by water content at a soil matric potential of $-1.5 \mathrm{MPa}$ ). In the work presented here, AWC was calculated over $1.70 \mathrm{~m}$ depth, since this corresponds to the maximum depth at which annual plant roots are observed in the study region. AWC approximates to the amount of water that can be absorbed by plant roots. To take into account climatic spatial variation, different statistical regressions were identified according to the climate station (Aniane, Béziers or Pézenas).

Fig. 6 shows a strong relationship between average wheat yield and AWC over the period 1977-1984. This relationship is nearly linear at large AWCs, but declines logarithmically below an AWC of approximately $10 \mathrm{~cm}$. The correlation coefficients are very high, which suggests that wheat yields can be estimated from the AWC under known climatic conditions.

Fig. 7 shows that for the HIGH change scenario a strong relationship exists between AWC and the change in wheat yield for the modified climatic conditions: larger AWC corresponds with stronger yield decreases. The shallow soil profiles (i.e. lowest AWC) exhibit no change at all. Under this scenario, the level of yield change is clearly related to changes in regional rainfall (Aniane, Pézenas, Béziers), with Aniane experiencing the highest absolute rainfall decrease and the highest yield decrease. At extremely low AWCs the relationship breaks down because the water stress is very high from the beginning.

Under the MID scenario (Fig. 8), the relationship observed between yield and AWC is much weaker. The only relationship between AWC and yield change is a yield increase on land with extremely shallow soil profiles. All other soil types experience a slight yield decrease. This is because the positive effect of increasing global radiation on shallow soil profiles prevails

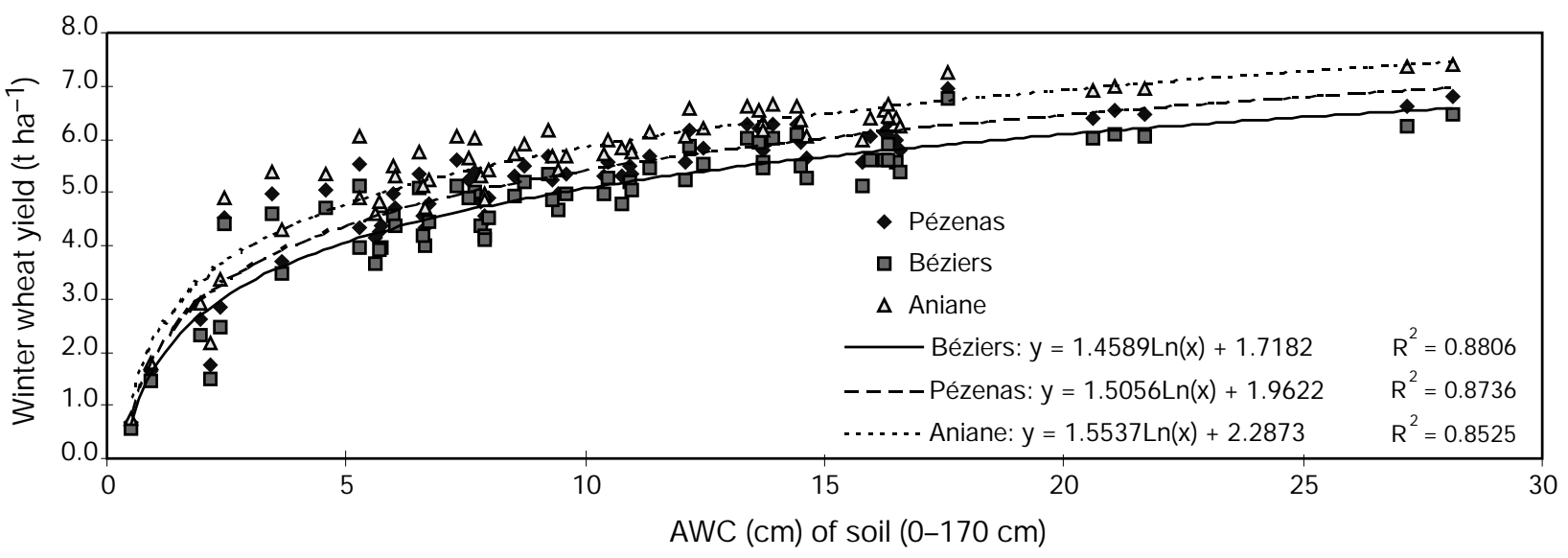

Fig. 6. Mean winter wheat yield over the total simulation period per soil profile, as a function of the available water capacity (AWC). Correlation coefficients of curves fitted to the data are shown on the graph 


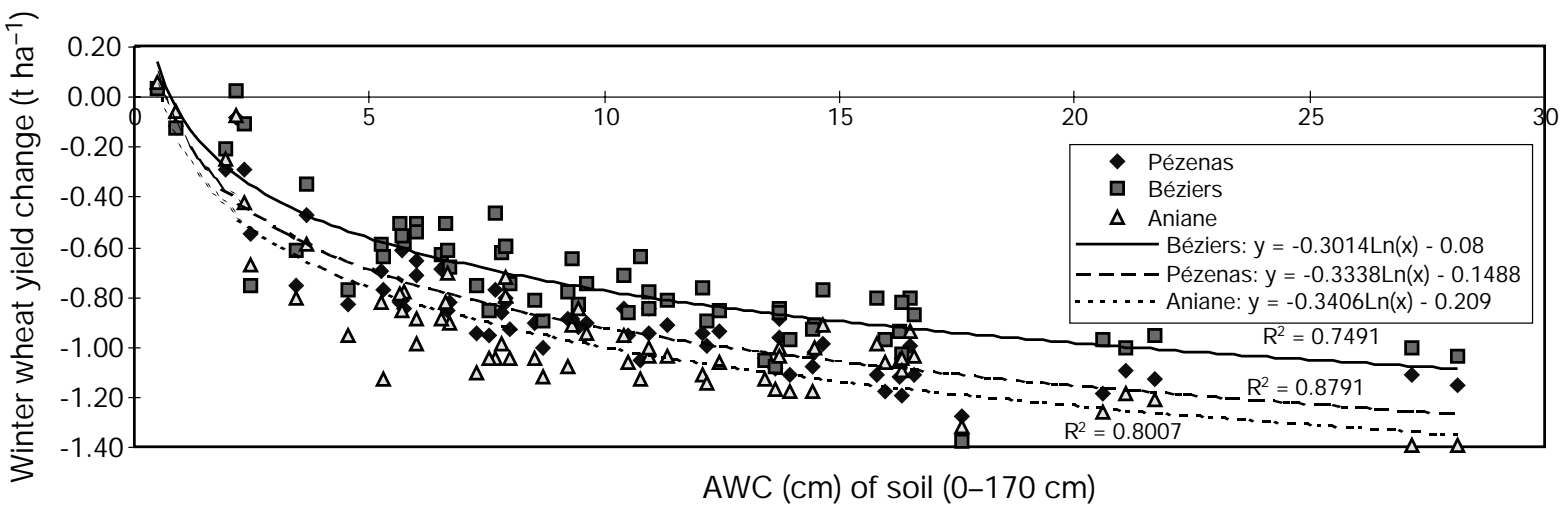

Fig. 7. Mean change in wheat yield (UKHI scenario), for each soil profile as a function of the AWC

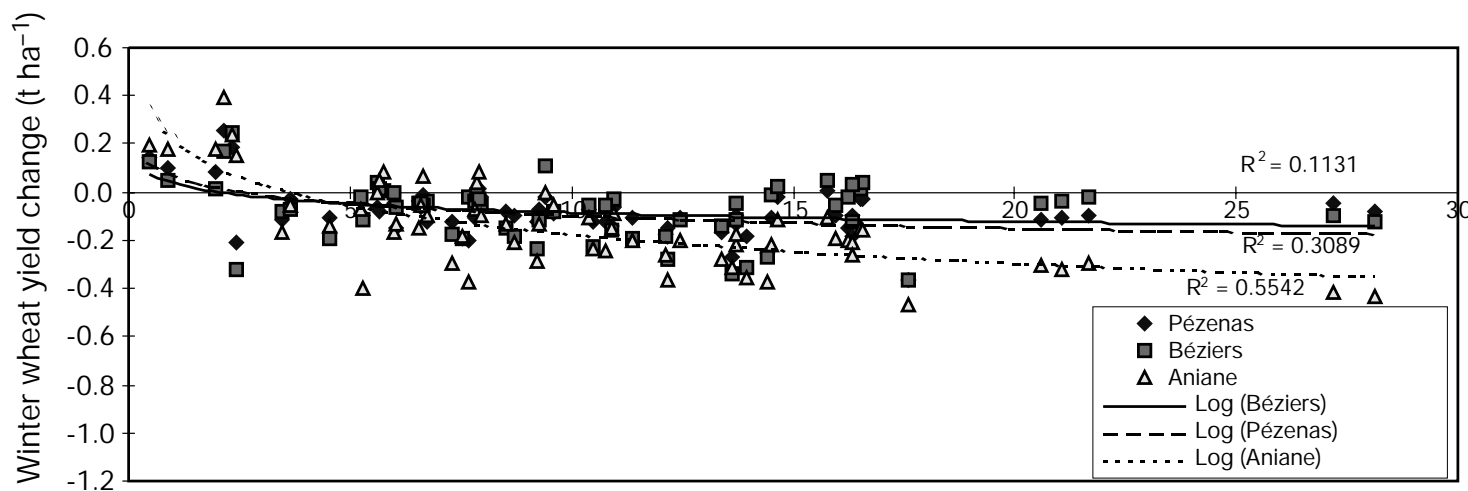

AWC $(\mathrm{cm})$ of soil $(0-170 \mathrm{~cm})$

Fig. 8. Mean change in wheat yield (HADCM 2 scenario), for each soil profile as a function of the AWC

over changes in the AWC. These profiles already have a very low AWC under the current climate and this is not strongly altered by the MID scenario rainfall changes. The climate with the highest rainfall (Aniane) shows the best correlation. This means that the predicted absolute rainfall change is in this case nearly sufficient to allow for a discriminating role of the AWC. Conversely, the correlation coefficient of Béziers is the lowest $\left(R^{2}=0.11\right)$. Under the LOW change scenario no AWC-yield change relationship was found.

\subsection{M apping wheat yields response indicators}

Maps of wheat yield and wheat yield change under future climatic conditions can be derived from the response curves obtained above. Examples of such maps are shown in Figs. $9 \& 10$. The AWC was obtained from the soil geographical data-
Fig. 9. Potential wheat yield, estimated on the basis of AWC of the dominant soil type within each map unit (soil map 1:250000; Bornand et al. 1994) and per climatic region (Béziers, Pézenas, Aniane)

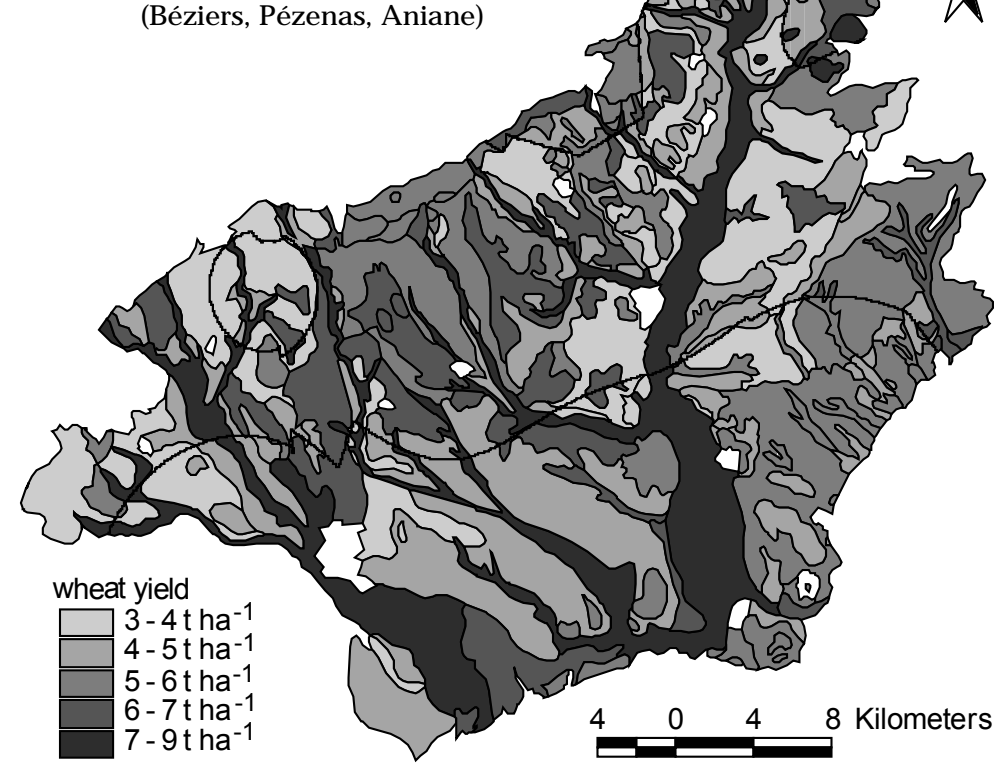


Fig. 10. Wheat yield change (for HIGH climate change), estimated on the basis of AWC of the dominant soil type within each map unit (soil map 1:250000; Bornand et al. 1994) and per climatic region

(Béziers, Pézenas, Aniane)

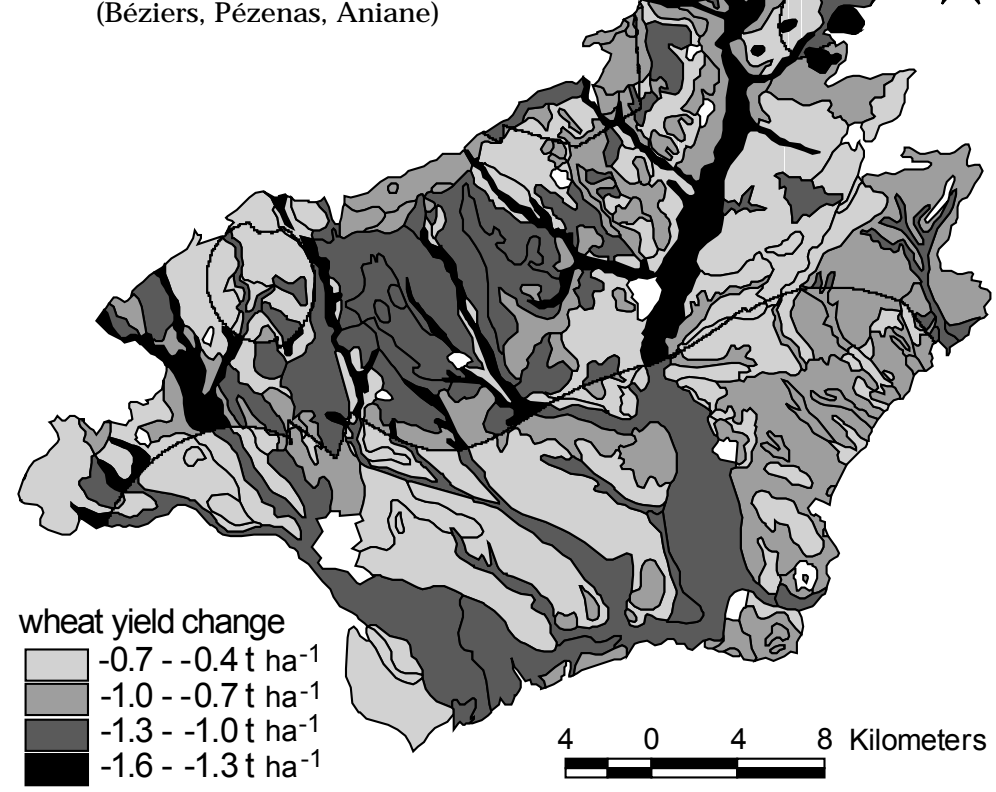

pattern to climate change, and could allow the identification of yield change class per soil type over the whole study area.

\section{CONCLUSIONS}

The modelling exercise of the response of spatially distributed wheat yields to climate change has shown the following:

(1) Spatial variability of the model responses was shown to be strongly affected by the soil variability within the study region when simulating yields for the current and potential future climate. The importance of soil variability in the study region results from 2 factors: (1) the small size of the study region favours the importance of soil variability over climatic variability and (2) water limitation, which is characteristic of Mediterranean regions. These observations explain why the results reported here are different from those of earlier studies (Easterling et al. 1998) which dealt with a coarser spatial resolution and wetter climate conditions. Thus, future research should seek as a matter of priority to integrate soil information in regional studies of climate change impact on agri-

base of Languedoc-Roussillon (Bornand et al. 1994). As the mapping units are complex, we considered only the mean AWC of the dominant soil type per soil mapping unit, i.e. the soil types that covers the largest area within the mapping unit. A climate map assigning a given climate (Béziers, Pézenas, and Aniane) to every location in the region was derived from a map of annual average rainfall obtained by interpolation between the 11 available rainfall stations of the region (see Fig. 3). The soil map and the climate map were then overlain using $\mathrm{ArC} / \mathrm{Info}^{\circledR}$ (by ESRI ${ }^{\mathrm{TM}}$ ) GIS (geographical information sytem). For each resulting soilclimate spatial unit the appropriate response curve was then applied.

The example in Fig. 9 illustrates the spatial impact of the soil type-wheat yield relationship established in this study. Only a slight influence can be attributed to the regional climate (i.e. rainfall) variation. In particular, we notice the absence of the lowest yield class in the northern climate region ( 3 to $4 \mathrm{t} \mathrm{ha}^{-1}$ ). The complex soil pattern creates important 'within-climate-region' variation and yield estimates remain fairly constant across the climate regions. Yield change distribution in this case (Fig. 10) is influenced by the regional variations in the future climate. Again, however, it appears that soil spatial variation determines the yield response culture if the studies are carried out at a large scale and over regions prone to water limitation.

(2) This study demonstrates also that integration of soil and climate variability can be performed without simplifying the simulation approach by using statistical models derived from simulations over a set of soil-climate situations representing the soil and climate variability of the region. Other sources of spatial variation, e.g. local variations of air temperature with landscape or local variations of climate sensitivity to global change, should not be neglected in future regional studies, and more research is required to estimate their effects.

(3) The predictions of climate change reported here exhibited strong variations across the study area depending on the climate sensitivity to $\mathrm{CO}_{2}$, the emission scenario and, moreover, the GCM. Significant winter wheat yield decreases were only observed for the climate scenario with the largest change. In all other cases, the influence of climate change on yields was weak. However, these results need to be tested by additional research that introduces factors that were not considered in this study, namely the influence of atmospheric $\mathrm{CO}_{2}$ concentration on crop growth and potential future changes in inter-annual climate variations. 
Acknowledgements. The research reported in this article was undertaken within the IMPEL project, and funded by the European Commission under the Climate and Environment Programme of Framework IV (contract no. ENV4-CT950114). The authors thank J. P. Barthès, Dr M. Bornand and P. Falipou for providing the soil data used in the study. M.D.A.R. was based at the Soil Survey and Land Research Centre, Cranfield University, when part of this work was undertaken and would like to thank M. J arvis for commenting on an earlier draft.

\section{LITERATURE CITED}

Armstrong AC, Legros J P, Voltz M (1996) ACCESS-II: a detailed model for crop growth and water conditions. Int Agrophys 10:171-184

Begon J C (1992) Evaluation des contraintes sol-climat sur la faisabilité des cultures, application au maïs grain et fourrage. CCE 5011, INRA, Orléans

Bindi M, Fibbi L, Gozzini B, Orlandini S, Miglietta F (1996) Modelling the impact of future climate scenarios on yield and yield variability of grapevine. Clim Res 7:213-224

Bonfils P (1993) Carte pédologique de la France au 1/100 000, feuille de Lodève. Notice + carte. INRA-SESCPF, Orléans

Bonnet A (1995) Calibration et validation du modèle de bilan hydrique Access II, sur 17 sites expérimentaux européens (blé et maïs). Programme CEE EV5V-CT92-0129, Mémoire Ecole Polytechnique de Lausanne

Bornand $M$, Barthès J $P$, Bonfils $P$ (1992) Carte des pédopaysages du Languedoc-Roussillon au 1:250 000. INRA, Montpellier

Bornand M, Legros JP, Rouzet C (1994) Les banques régionales de données-sols. Exemple du LanguedocRoussillon. Etud Gestion Sols 1:67-82

Braun P, Guiroy D, Calvie RM, Emanuel J M, Raffy M H (1990) Premiers résultats 1990, céréales et protéagineux. Rapport, Institut Technique des Céréales et Fourrages, bureau régional de Nimes

Childs SW, Gilley J R, Splinter WE (1977) A simplified model of corn growth under moisture stress. Trans ASAE 20 (5): 858-865

Conde $C$, Liverman $D$, Flores $M$, Ferrer $R$, A raujo $R$, Betancourt E, Villarreal G, Gay C (1997) Vulnerability of rainfed maize crops in Mexico to climate change. Clim Res 9: $17-23$

Debaeke Ph, Cabelgenne M, Casals M L, Puech J (1996) M ise au point et test d'un modèle de simulation de la culture de blé d'hiver en conditions d'alimentation hydrique et azotées variées: EPICPHASE - blé. Agronomie 16:25-46

Easterling WE, Weiss A, Hays CJ , M earns LO (1998) Spatial scales of climate information for simulating wheat and maize productivity: the case of the US Great Plains. Agric For M eteorol 90:51-63

FAO-UNESCO (1981) Soil map of the world at 1:5.000.000. Food and Agriculture Organization, Rome

Favrot J (1989) Une stratégie d'inventaire cartographique à grande échelle: la méthode des secteurs de référence. AFES Science Sol 27 (4):351-368

Feddes RA, Kowalik PJ , Zaradny H (1978) Simulation of field water use and crop yield. Pudoc, Wageningen

Floret C, Pontanier R, Rambal S (1982) Measurement and modelling of primary production and water use in south Tunisian steppe. J Arid Environ 5:77-90

Henric J F, Legros JP, Slawinski C, Walczak RT (1996) Yield prediction for winter wheat in eastern poland (Grabow) using the ACCESS II model. Int Agrophys 10:239-247
Hulme M, Raper SCB, Wigley TML (1995) An integrated framework to address climate change (ESCAPE) and further developments of the global and regional climate modules (M AGICC). Energy Policy 23:347-355

IPCC (1995) Climate change 1995: the science of climate change. Houghton JT, M eiro Filho LG, Callendar BA, Harris N, Kattenburg A, Maskell K, Cambridge University Press, Cambridge

ITCF (Institut Technique des Céréales et des Fourrages) (1990) Premier résultats 1990-céréales et protéagineux. Bureau régional de Nîmes (Gard, Hérault, Bouches du Rhône), ITCF, Paris

Kenny GJ , Harrison PA (1992) Thermal and moisture limits of grain maize in Europe: model testing and sensitivity to climate change. Clim Res 2:113-129

Kessler J , Chambraud A (1986) La météo de la France, tous les climats localité par localité. Editions J C Lattès, Rungis

Leenhardt D (1991) Spatialisation du bilan hydrique. Propagation des erreurs d'estimation des caractéristiques du sol au travers des modèles de bilan hydrique. Cas du blé dur d'hivers. PhD thesis, ENSAM - INRA, M ontpellier

Leenhardt D, Voltz M, Bornand M, Webster R (1994) Evaluating soil maps for prediction of soil water properties. Euro J Soil Sci 45:293-301

Legros JP, Bonnet A (1996) Calibration and validation of EuroACCESS. In: Loveland PJ, Rounsevell MDA (eds) EurOACCESS. Soil Survey and Land Research Center, Cranfield University, Ed European Community, Silsoe, p 124-132

Legros J P, Baldy C, Fromin N, Bellivier D (1994) Crop models: principle and adaptation to the problem of climate change. In: Rounsevell MDA, Loveland PJ (eds) Soil responses to climate change. NATO ASI Series: Global environmental change no. 23. Springer-Verlag, Berlin, p 72-98

Legros J P, Leenhardt D, Voltz M, Cabelguenne M (1996) Scientific basis of EuroACCESS-II. In: Loveland PJ , Rounsevell MDA (eds) EuroACCESS. Soil Survey and Land Research Center, Cranfield University, Ed European Community, Silsoe, p 19-34

Loveland PJ, Rounsevell MDA (1996) EuroACCESS, a spatially distributed, soil, agro-climatic and soil hydrological model to predict the effects of climate change on land-use within the European Community. Soil Survey and Land Research Center, Cranfield University, Ed European Community, Silsoe

Loveland PJ , Legros J P, Rounsevell MDA, de la Rosa D, Armstrong A (1994) A spatially distributed soil agroclimatic and soil hydrological model to predict the effects of climate change within the European Community. Proc Int Congr Soil Sci, Acapulco 6a(V):83-100

Rambal S, Cornet A (1982) Simulation de l'utilisation de l'eau et de la production végétale dans une phytocoenose sahélienne du Sénégal. Acta Oecol Oecol Plant 3(17):381-397

Ritchie J T (1972) M odel for predicting evaporation from a row crop with incomplete cover. Water Resour Res 8: 1204-1261

Rounsevell MDA, Armstrong AC, Audsley E, Brown O, Evans S, Gylling M, Lagacherie P, Margaris N, Mayr T, de la Rosa D, Rosato P, Simota C (1998) The IMPEL project: integrating biophysical and socio-economic models to study land use change in Europe. In: Proceedings of the World Congress of Soil Science, M ontpellier, August 1998. International Soil Science Society, M ontpellier. CD-ROM

Statistiques Agricoles, 1977-1984. Annuaires régionaux de statistique agricole pour les années 1977 à 1984 en Languedoc-Roussillon. Ministère de l'A griculture, Paris

Van Keulen H (1975) Simulation of water use and herbage 
growth in arid regions. Simulation monographs. Pudoc, Wageningen

Van Lanen HAJ, Van Dieppen CA, Reinds GJ, de Koning GHJ , Bulens J D, Bregt AK (1992) Physical land evaluation methods and GIS to explore the crop growth potential and its effects within the European Communities. Agric Syst 39:307-328

Weir AH, Bragg PL, Porter J R, Rayner JH (1984) A winter

Editorial responsibility: Mike Hulme,

Norwich, United Kingdom wheat crop simulation model without water or nutrient limitations. J Agric Sci Camb 102:371-382

Williams J R, J ones CA, Kiniry J R, Spanel DA (1989) The EPIC CROP growth model. Trans ASAE 32(2):497-511

Wolf J, Evans LG, Semenov MA, Ackersten $H$, Iglesias A (1996) Comparison of wheat simulation models under climate change. I. M odel calibration and sensitivity analyses. Clim Res 7:253-270

Submitted: M ay 5, 1998; Accepted: February 2, 1999 Proofs received from author(s): A pril 19, 1999 